\title{
COVID-19 in Uganda: Epidemiology and Response
}

\author{
Esther Ejiroghene Ajari ${ }^{1,2,3^{*}}$ (D), Andrew Marvin Kanyike ${ }^{4}$ (D) Daniel Ojilong ${ }^{4}$ (D), \\ Ibrahim Olawale Abdulbasit ${ }^{5}$ \\ ${ }^{1}$ College of Medicine, University of Ibadan, Ibadan, Oyo State, Nigeria \\ ${ }^{2}$ The TriHealthon, Ibadan, Oyo State, Nigeria \\ ${ }^{3}$ Center for Contemplative Science, University of Virginia, Charlottesville, United States of America \\ ${ }^{4}$ Faculty of Health Sciences, Busitema University, Mbale, Uganda \\ ${ }^{5}$ College of Health Sciences, Ahmadu Bello University, Zaria, Kaduna State, Nigeria \\ * Corresponding author: Esther Ejiroghene Ajari E-mail: estherejiroghene@gmail.com ORCID: 0000-0001-8593-3886 \\ Received: 6 April 2020 Accepted: 7 May 2020
}

\begin{abstract}
Uganda has had a relatively large share of zoonotic disease outbreaks in the past and this has impacted its preparedness and response level in combatting the COVID-19 outbreak in the country. Compared to most countries in the East African Community, Africa and the world, Uganda seems to be effectively curtailing the spread of the virus and managing the disease despite its relatively weak healthcare system and economy. The first COVID-19 case was confirmed on March 21 st, 2020 and as at May 6th, 2020, there has only been 100 cases confirmed from 47,620 tests carried out. Also, as at this date, there has been 55 recoveries and no reported death from the disease. These promising statistics prompts the development of this paper to detail the epidemiology of the disease in the country and discuss the response of the government and other stakeholders to the outbreak.
\end{abstract}

Keywords: Coronavirus, Uganda, epidemiology

\section{INTRODUCTION}

SARS-CoV-2, the novel coronavirus, previously designated as 2019-nCoV, was identified as a cause for a string of pneumonia-like cases in Wuhan City of Hubei Province, China in December, 2019 [1]. It is a highly infectious and transmissible virus, with RO of up to 6.49 (RO being the average number of new infections produced by an infectious person without any control measures) [2]. As at May 6th, 2020, there has been 3,588,773 confirmed cases of COVID-19 globally with 247,503 deaths, 33,973 cases in Africa with 1,202 deaths, and 1,441 cases in East African
Community (EAC) with 42 deaths [3]. The Coronavirus Disease 2019 (COVID-19) outbreak in Uganda occurs at such a time when the country has had a relatively large share of zoonotic disease outbreaks, all in regular successions, over the past few years. Between 2009 to 2014, the country experienced eight of such outbreaks [4] and three more between 2017 to 2018 [5]. Also, the country successfully managed six outbreaks of Ebola Virus Disease in 2000, 2001, 2007, 2008, 2012 and 2018 [6]. Furthermore, the country sent a delegation of 20 experts to Liberia and Sierra Leone to help combat the deadliest Ebola outbreak, yet, in West 
Africa's history which lasted from 2013 to 2016 [7-9]. These experiences have not left the country without lessons learned, thus, impacting her preparedness and response level, but not without challenges. This paper discusses the epidemiological aspects of the COVID-19 outbreak in Uganda and the country's response to the situation.

\section{REVIEW}

At the end of May 6th, 2020, Uganda had confirmed 100 COVID-19 cases [3]. This figure includes 39 truck drivers from Kenya, Tanzania, and Burundi who were identified at the inter-country border testing points [10] and are included as part of Uganda's statistics due to the World Health Organization (WHO) regulations that positive cases be counted and treated in the country they were tested in [11]. Uganda's figures remain one of the lowest in Africa and the third lowest among member states of the East African Community with 535 cases in Kenya, 480 cases in Tanzania, 261 cases in Rwanda, 19 cases in Burundi and 49 cases in South Sudan [3]. Also, as at this date, unlike most countries, there has been no reported case of death from COVID-19 in Uganda [3] and no health worker, managing the country's confirmed cases, has contracted the virus [10].

\section{Before the Index Case Confirmation}

On February 5th, 2020, 47 days before the first confirmed case of COVID-19 in Uganda, the Minister of Health in her update to the public divulged that they had, since, intensified vigilance and surveillance to quickly identify cases, and had instituted an inter-ministerial committee, led by the Prime Minister, to oversee preparedness coordination [13]. Such a multi-sectoral approach to preparing for a future outbreak of the disease has shown great results in countries such as Hong Kong, Singapore and Japan [14]. Screening at the Entebbe International Airport for all arriving travelers started on January 20th, 2020 [15], 10 days after the WHO issued a comprehensive package of technical guidelines (containing advice on how to detect, test and manage potential cases) to its regional emergency directors [16]. The screening checked for main symptoms of COVID-19, especially fever, cough, fatigue and dyspnea, documented from earlier studies in Wuhan, China [13,14]. Also, since the commencement of screening at the airport, the Ministry of Health encouraged all travelers to go under self or institutional quarantine as they monitored development of symptoms for 14 days, the maximum incubation period of the virus [19].

As the number of cases worldwide continued on a meteoric rise, the Ministry of Health issued a recommendation of hygienic practices for curbing the spread of the SARS-CoV-2 contagion. These recommended practices include: avoiding contact with people with flu-like symptoms; avoiding crowds if one has flu-like symptoms; covering mouth and nose while sneezing; avoiding touching of the mouth, eyes and nose; frequent washing or sanitizing of hands, especially in public places, with soap and water or alcohol-based sanitizers; regularly cleaning and disinfecting touched objects; and avoiding handshakes and hugs [20]. Furthermore, the Ugandan president addressed the nation, issuing a 13-point directive on March 18th, 2020, 3 days before the country's index case confirmation [21] and a week after the WHO Director-General declared COVID-19 a global pandemic [22]. This address became the first of many of such addresses given, almost weekly, by the Head of State, issuing more guidelines and directives with each address. Key among the directives were: closure of all educational institutions; suspension of religious, political, cultural and all other forms of meetings/gatherings of more than 10 people (except burial ceremonies which were limited to only members of the affected homestead); ban on the movement of residents of Uganda to or through the, then designated, "category one" countries; suspension of open air markets, public marriage ceremonies, bars, sports shows and concerts; provision of standard operating procedures for hotels and public and private transport systems; encouragement of Ugandan residents to adopt the hygienic practices recommended by the Ministry of Health; mandating institutional quarantine (at governmentselected hotels) of travelers returning from the, then, "category one" countries and recommending selfquarantine for other returning travelers [21]. However, six Chinese nationals who were placed on institutional quarantine escaped the Kibuli Hotel Africa where they were being quarantined on March 19th, 2020. A day later, they were apprehended alongside their Ugandan driver and his wife in Zombo district (in West Nile region of Uganda) when they were about to cross into the neighboring Democratic Republic of Congo, having travelled through the country and, possibly, making contacts with hundreds of people. Two of these men subsequently tested positive for the virus and they were, all, charged and convicted for violation of, among others, the Public Health (Control of COVID - 19) Rules, 2020 [23]. They are to be sentenced on May 4th, 2020 [23].

\section{On Confirmation of the Index Case}

Uganda reported its first case of COVID-19 on March 21st, 2020, 10 days after the WHO Director-General declared the disease a pandemic [12]. The index patient, a 36 year old 
Ugandan male arriving from Dubai, United Arab Emirates (UAE) after a week-long trip, was isolated at Entebbe grade $B$ hospital for monitoring after screening at the Entebbe International Airport detected his abnormally high temperature [24]. Efforts and appeals were made to locate the 84 travelers, who were in the same plane as the index patient, but were, unfortunately, not institutionally quarantined on arrival due to the fact that UAE was not listed as a "category one" country then. Also, the Ministry of Health issued a public appeal that all those who had travelled back from the UAE in the past weeks should report for testing but only a portion of them did, out of which some confirmed cases were reported [25]. At the time, 292,142 total confirmed cases and 26,069 newly diagnosed cases had been reported globally with 81,498 cases in China, the epicenter of the pandemic; 153 cases in $U A E$, the country from where the Ugandan index case was imported; and 739 cases in Africa [26]. Furthermore, at that time, all Uganda's neighboring countries had confirmed cases of the disease except South Sudan: Democratic Republic of Congo (23 cases), Kenya (7 cases), Tanzania (6 cases), and Rwanda (17 cases) [26]. The confirmation of the index case in Uganda, the rising statistics in the world, and the fact that not all those who returned from UAE in the past few weeks reported back for testing prompted the Ugandan government to make institutional quarantine compulsory for all those travelling to the country. Returning travelers were made to cover the cost of quarantine which was sometimes as high as 840 USD [27]. This high cost led to public outcry and to cases of travelers providing some immigration officials with bribes so they could evade quarantine [28].

\section{After Index Case Confirmation}

Due to the increasing cases globally and the issue of escape from quarantine centers, the government locked down all the country's borders (land, air and water) and prohibited all pedestrian entry and exit into the country (even that of refugees despite its Open-Door policy). However, exemptions were made for cargo and emergency United Nations aircrafts and vehicles but these were limited to carry only the crew and three persons respectively [29]. A key drawback to this exemption is that cargo truck drivers were allowed to continue inland before their test results were known. An example of the manifestation of this drawback is when a Kenyan cargo driver's test came back positive after he had travelled hundreds of kilometers and had 55 confirmed contacts, possibly more, in a space of about 24 hours, the average turnaround time for the test. Kenya, the country where the driver travelled from, had more confirmed COVID-19 cases at the time. An additional preventive measure put in place is the ban on public intracountry transportation announced on March 25th, 2020. However, private vehicles were allowed to operate as long as they carried only three passengers who must be members of the same family. Exemptions were also made for ambulances, army vehicles, garbage trucks and other emergency vehicles. Furthermore, residents of the country were advised to limit non-essential travels and use bicycles for essential travel if they do not afford any other means of private transportation [29].

Following the index case confirmation, additional directives such as social distancing and wearing of face masks especially when suffering from acute respiratory symptoms (cough, sneeze, fever etc.) were given. The government also established telephone hotlines for people to report symptoms of themselves or of those suspected to be harboring infection. In addition, Uganda's efforts, like most African and European countries, were boosted by donations from Jack Ma, a Chinese billionaire and the Founder of Alibaba Group. Uganda received its consignment of 100,000 masks, 20,089 test kits, 741 PPEs and 1,111 face shields on March, 24th, 2020 [30].

By March 30th, 2020, the number of cases in Uganda had risen to 33, most being imported cases from Dubai, others from Afghanistan, United States of America and United Kingdom [31]. 14 of the 33 cases had already mixed with the community having not been initially identified at the airport or due to the fact that they escaped from quarantine [29]. Thus, efforts were made to identify all those who the 14 patients had been in contact with. Also, there were four reported cases of community transmission. This includes an 8-month old baby whose father had returned from Kisumu in Western Kenya, and a trader in Elegu border town of Adjumani district in Northern Uganda who was on the Uganda-South Sudan border but had no previous international travel history [29]. By then, South Sudan had not yet reported any confirmed case. The threat of further community transmission prompted the president to introduce more stringent preventive measures. These include: prohibition of movement of people by all forms of transportation; nationwide curfew from 7:00pm to 6:30am (local time); closure of all businesses and shops and suspension of all their activities (except for established food markets and stores, hospitals and pharmacies); and the instruction of all workers (except medical personnel and members of District Task forces who were charged with management of health emergencies) to remain at home or work from home [32]. 
At this point, the country was effectively on lockdown. This lockdown was slated to last for 14 days effective from April 1st, 2020 [29]. Also, the above restrictive measures being issued one after the other, barely few hours apart, were received with mixed feelings by the public as people had to adjust to the drastic changes and some claimed that without working, they could die faster from hunger than from the dreaded disease since they live a hand-to-mouth kind of life [33,34]. The 2015 Uganda Bureau of Statistics fact sheet shows that $87.2 \%$ of Ugandans are in informal employment thus, validating the "hand-to-mouth kind of life" claim [35]. Due to the non-receptivity of some members of the public to these legislations, they, on many instances, engaged in running battles with the security authorities, especially in the Kampala and Wakiso districts [36]. In light of this, the government concerted efforts with private organizations, non-governmental organizations, developmental partners and utilized the funds and non-monetary donations made to them by these entities (as well as various well-meaning individuals) to provide a relief package of food to about 1.5 million residents of the country, especially the sick, elderly, pregnant and lactating mothers, and drivers/riders of public transportation vehicles. The package per person comprises 6 kilograms of maize flour, 3 kilograms of beans, 3 kilograms of salt plus 2 kilograms of powdered milk and 2 kilograms of sugar for pregnant and lactating mothers and the sick [37]. However, this package was distributed only in the urban poor areas of Kampala and Wakiso districts leading to public uproar [37]. In fact, the parliamentary speaker and members initially opposed the restricted distribution of food and suggested that government considers nationwide food distribution but this was overlooked and distribution commenced as earlier planned [38]. As at April 14th, 2020, there were 54 confirmed cases and this growing number prompted the government to extend the lockdown for another 21 days [39].

On April 28th, 2020, a week ahead of set deadline for lock down, Uganda had 79 confirmed cases and the president gave his $12^{\text {th }}$ televised national address where he said that a team of experts had been put together study the status of Uganda's COVID-19 fight to inform new guidelines before the expiry of the lockdown period [40]. He revealed that the results of the survey will be availed on May 4th, 2020 as he would be addressing the nation once again [40]. Uganda is the first country in the EAC to carry out this rapid assessment survey which targets a representative population of Uganda with the aim of estimating prevalence of COVID-19 among Ugandan communities [40]. On May 4th, 2020, Uganda had confirmed 97 cases and the president addressed the nation once again revealing that 601 tests had been carried out as part of the rapid assessment survey yielding only 1 positive case so far [41]. He partially lifted the lockdown directing that: food markets remain open; warehouses, wholesale, hardware, garages, metal and wood workshops open up, restaurants as well but only those offering takeaway; a quota of 30 lawyers be permitted to work on essential legal cases; airport, borders, schools and other facilities that attract large numbers of people stay closed; and public and private cars remain non-operational. All other previous issued protective measures were to stay in place for another 14 days as the rapid community survey paints a clearer picture [41].

As at May 6th, 2020, 55 patients have been discharged after testing negative to the coronavirus [42]. According to the Director General of the Ugandan Health services, the recovered patients are being treated with Hydroxychloroquine and Erythromycin [43]. Also, as at this date, a total of 2,248 individuals who were in contact with the confirmed cases have been listed. Of these people, the Ministry of Health reports that 808 of them are still undergoing follow-up [44]. Also, as at this date, a cumulative of 47,620 tests have been carried out [45]. This figure includes both the initial and repeat tests carried out on confirmed and quarantined cases before discharge. By comparison, South Korea was doing an average of 10,000 tests per day during the peak of the outbreak there [46]. This response was crucial to the management of the pandemic and its associated effects in South Korea, thus, allowing the nation to be one of only a handful of nations (Mali, France and Australia) to hold an election amidst the pandemic. However, affording this level of massive testing is not feasible in Uganda due to its poor economy. Uganda currently has capacity to run 500 tests per day, each costing about 65 USD $[29,48]$, but even the long-term sustenance of this relatively low testing capacity by the country is not feasible. This is unfortunate considering the growing consensus among scientists that massive testing is key to curtailing spread of the virus since the number of cases receiving attention depends on the number of tests carried out [49]. Thus, it is expedient that cheaper test options be sought.

A study, using exponential growth model, predicted that without proper intervention, there will be an exponential rise in the number of infected individuals in Uganda with estimates of about 127 new cases in 14 days [50]. Also, the Ugandan Minister of Health, on April 2nd, 2020, revealed that using models that were not divulged, the country could have potentially peaked over 18,000 cases with 566 deaths by the end of April if restrictive measures were not put in 


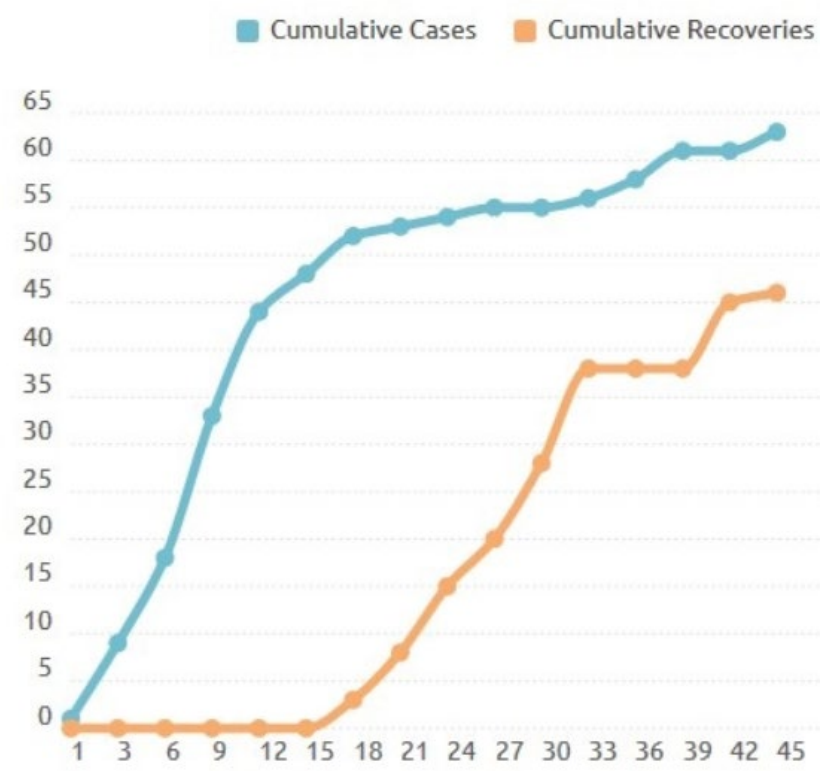

Figure 1. Graphic Representation of the cumulative COVID-19 confirmed cases and recoveries in Uganda plotted against the number of days after the index case confirmation. Retrieved May 6th, 2020 (source: https://covid19.gou.go.ug/)

\section{Age distribution of cases}

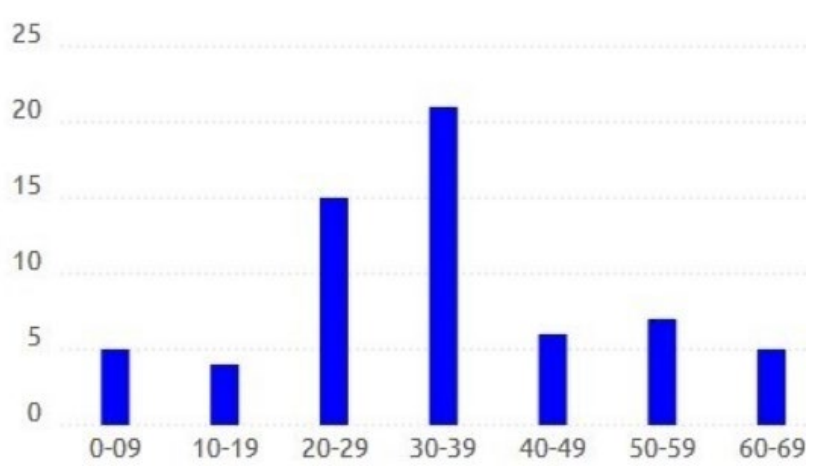

Figure 2. Graphic Representation of the age distribution of COVID19 cases in Uganda. Retrieved May 6th, 2020 (source: https://covid19.gou.go.ug/)

place [51]. Figure 1 depicts that the country is way below these projections.

Figure 2 shows that the highest cases are among the age group of 30 to 39 years. This is similar to the overall situation in Africa, as reported on April 15th, 2020 [52]. This modal frequency among relatively younger populations coupled with the fact that mortality rate increases with age [53] probably explains the zero death incidence in Uganda and the low death rate in Africa compared to America and European countries like Italy where most patients are of older age groups $[54,55]$.

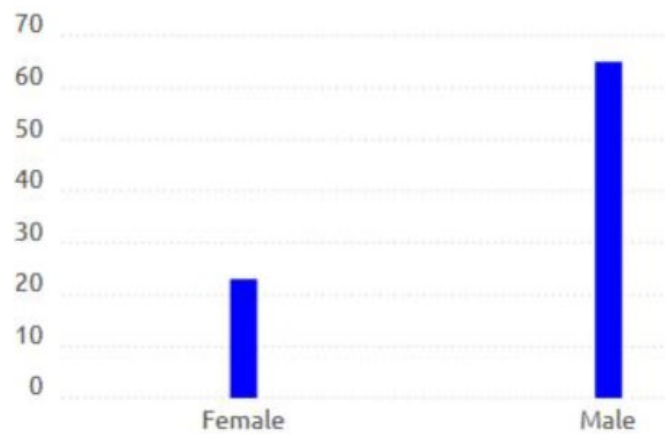

Figure 3. Graphic Representation of the sex distribution of COVID19 cases in Uganda. Retrieved May 6th, 2020 (source: https://covid19.gou.go.ug/)

It is also reported that men are more infected than women [56] and Figure 3 shows that the situation is not any different in Uganda. Many scholars highlight the behavioral patterns of males as the reason for this epidemiological pattern. However, there has not been any concrete proof to back up this claim.

Figure 4 shows that Kampala and Wakiso, the districts that posed the most resistance to COVID-19 preventive legislations (as discussed above), has the highest number of cases, 21 and 19 respectively. This might, however, be due to the fact that Entebbe International Airport, the only international airport in the country, is located in Wakiso district near Kampala, and many institutional quarantine and treatment centers are located in these two districts. Also, these two districts have the highest population densities and are the most populous in Uganda [57].

\section{CONCLUSION}

The early establishment of strict measures has paid off in countries such as Singapore, Japan and Hong Kong which are handling the pandemic better than many other developed countries [58]. Some studies from Wuhan, the initially most hit city, credit the city's flattening of the curve to the intense social distancing and lockdown situation in the city $[59,60]$. Also worth noting is that countries like Tanzania which failed to promptly impose lockdown legislations have experienced an abrupt rise in cases underscoring the benefits of these restrictions. However, these restrictions are not enough. Figure 1 which depicts an almost flattened curve in Uganda might be a faux representation of reality considering the issues of poor adherence to institutional quarantine measures by residents of Uganda and asymptomatic transmission of the virus which cannot be detected and curtailed due to the low level 


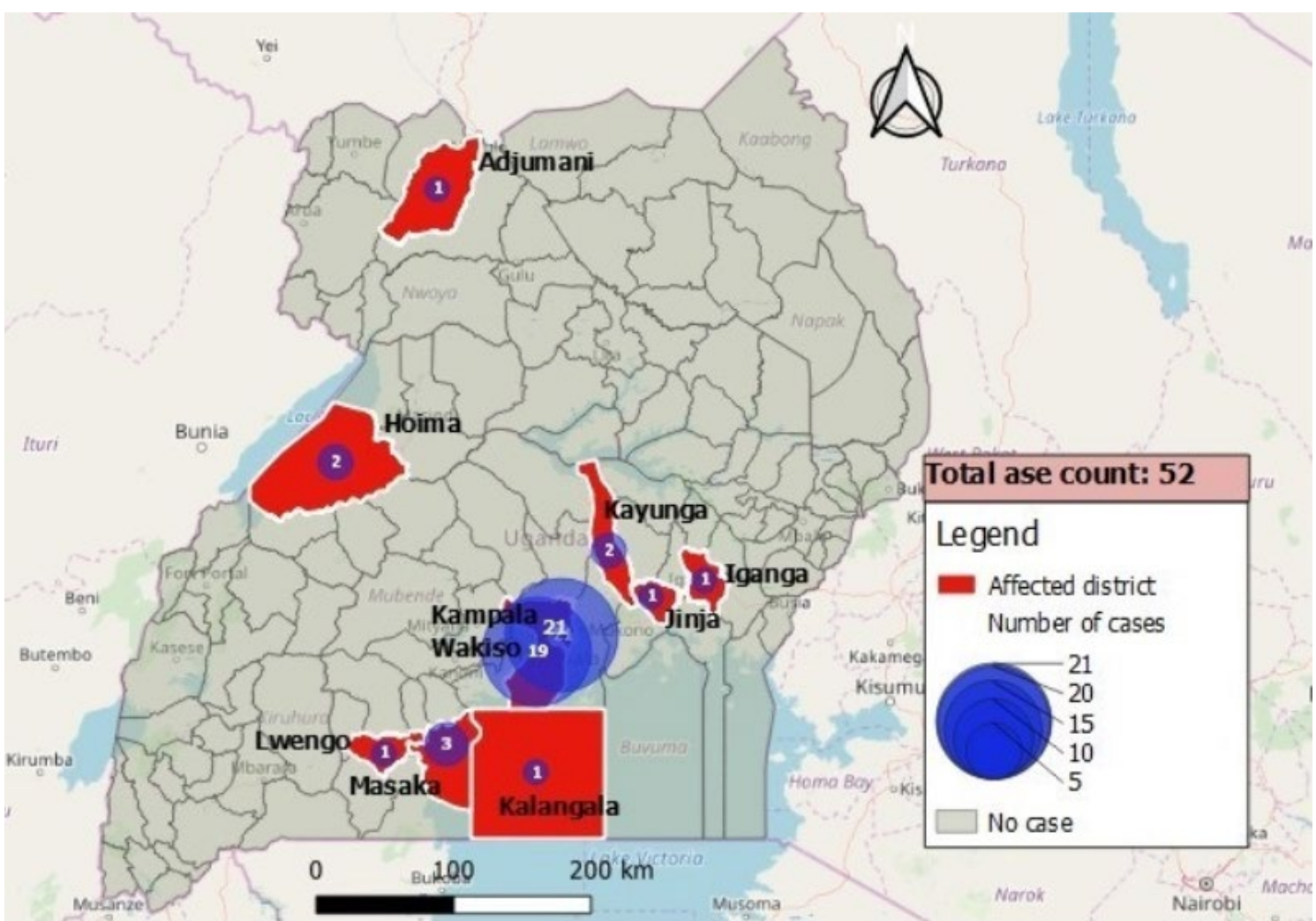

Figure 4. Distribution of the confirmed COVID-19 cases in Uganda by place of residence. Retrieved May 6th, 2020. (Source: https://covid19.gou.go.ug/)

of testing in the country. The latter issue could also increase the chances of resurgence when the lockdown is lifted. The WHO Director-General supports this hypothesis when he called on all countries that have enforced the lockdown measures to explore aggressive measures for isolating, testing and tracing suspected carriers of the virus as well as treating patients infected with the virus [61]. He further acknowledged that this is the fastest way out of the extreme social and economic restrictions necessitated by the virus and the best way to prevent future transmission of the virus [61]. Also, a study, utilizing a mathematical model design, showed that a one-time lockdown of a country will be insufficient to curtail spread of the virus yet intermittent distancing measures without other interventions can only control the pandemic up to 2022 [62]. Therefore, Uganda needs to lay witty strategies for phased lifting of the lockdown, upgrade preventive and management strategies, introduce novel interventions, and carefully monitor and evaluate outcomes before conclusions can be made that the country has effectively managed the virus.

\section{DECLARATION OF CONFLICT OF INTEREST}

The authors received no financial support for the research and/or authorship of this article. There is no conflict of interest.

\section{REFERENCES}

1. Gupta PK, Bhaskar P, Maheshwari S. Coronavirus 2019 (COVID-19) Outbreak in India: A Perspective so far. J Clin Exp Invest. 2020;11(4):em00744. (doi: 10.5799/jcei/8220).

2. Liu Y, Gayle AA, Wilder-Smith A, Rocklöv J. The reproductive number of COVID-19 is higher compared to SARS coronavirus. J Travel Med. 2020; 27(2):1-4. (doi: 10.1093/jtm/taaa021).

3. World Health Organisation. Coronavirus disease 2019 (COVID-19) Situation Report - 91. 2020;(06 May). Available at: https://www.who.int/emergencies/ diseases/novel-coronavirus-2019/situation-reports

4. Nabukenya I, Lukwago L, Okot C, Wamala JF, Malimbo M, Namukose EM, et al. Is Uganda a hub for zoonotic disease outbreaks? Lessons and challenges from ebola, marburg, yellow fever and anthrax outbreaks. Int J Infect Dis. 2014;21:238. (doi: 10.1016/j.jijid.2014.03.916).

5. Mbonye AK, Sekamatte M. Disease outbreaks and reporting in Uganda. Lancet. 2018;392(10162):2347-8. (doi: 10.1016/S0140-6736(18)32414-0). 
6. CDC. Ebola Virus Disease Distribution Map: Cases of Ebola Virus Disease in Africa Since 1976. 2019 [cited 2020 May 1]. Available at: https://www.cdc.gov/vhf/ebola/ history/distribution-map.html

7. Paulat L. Uganda Sends 20 Experts to Aid in Ebola Crisis | Voice of America - English. [cited 2020 Apr 26]. Available at: https://www.voanews.com/science-health/ugandasends-20-experts-aid-ebola-crisis

8. Byaruhanga C. Ebola outbreak: What Uganda can teach West Africa - BBC News. [cited 2020 Apr 24]. Available at: https://www.bbc.com/news/world-africa-28743595

9. Jacobsen $\mathrm{KH}$, Alonso Aguirre $\mathrm{A}$, Bailey $\mathrm{CL}$, Baranova $\mathrm{AV}$, Crooks AT, Croitoru A, et al. Lessons from the ebola outbreak: Action items for emerging infectious disease preparedness and response. EcoHealth. 2016;13:200-12. (doi: 10.1007/s10393-016-1100-5).

10. Ugandan Ministry of Health. Update on the Covid-19 Outbreak in Uganda - Ministry of Health | Government of Uganda. [cited 2020 May 8]. Available at: https://www.health.go.ug/cause/update-on-the-covid19-outbreak-in-uganda-4/

11. World Health Organization. International Health Regulations. 2005 [cited 2020 May 1]. Available at: https://www.afro.who.int/sites/default/files/201706/international_health_regulations_2005.pdf

12. Uganda Ministry of Health. Update on the COVID-19 response in Uganda - Ministry of Health | Government of Uganda. [cited 2020 May 1]. Available at: https://www.health.go.ug/cause/update-on-the-covid19-response-in-uganda/

13. Jane Ruth A. Update on Uganda's preparedness situation following the 2019 Novel Coronavirus outbreak in China and other countries around the World | WHO | Regional Office for Africa. 2020 [cited 2020 Apr 24]. Available at: https://www.afro.who.int/news/update-ugandaspreparedness-situation-following-2019-novelcoronavirus-outbreak-china-and

14. Legido-quigley $\mathrm{H}$, Asgari N, Teo YY, Leung GM, Oshitani $\mathrm{H}$, Fukuda $\mathrm{K}$, et al. Are high-performing health systems resilient against the COVID-19 epidemic? Lancet. 2020;395(10227):848-50. (doi: 10.1016/S01406736(20)30551-1).
15. The Independent. Timeline of Uganda's response to COVID-19. 2020 [cited 2020 Apr 24]. Available at: https://www.independent.co.ug/timeline-of-ugandasresponse-to-covid-19/

16. World Health Organization. WHO Timeline - COVID-19. [cited 2020 Apr 24]. Available at: https://www.who.int/news-room/detail/08-04-2020who-timeline---covid-19

17. Xu Z, Shi L, Wang Y, Zhang J, Huang L, Zhang C, et al. Pathological findings of COVID-19 associated with acute respiratory distress syndrome. Lancet Respir Med. 2020;8(4):420-2. (doi: 10.1016/S2213-2600(20)30076-X).

18. Guan W, Ni Z, Hu Y, Liang W, Ou C, He J, et al. Clinical Characteristics of Coronavirus Disease 2019 in China. N Engl J Med. 2020; 382:1708-1720. (doi: 10.1056/NEJMoa2002032).

19. Backer JA, Klinkenberg D, Wallinga J. Incubation period of 2019 novel coronavirus (2019-nCoV) infections among travellers from Wuhan, China, 20-28 January 2020. Euro Surveill.2020;25(5):pii=2000062.

(doi: 10.2807/15607917.ES.2020.25.5.2000062).

20. Ministry of Health Uganda.:: $\mathrm{MoH}::$ COVID-19 Information Portal [Internet]. 2020 [cited 2020 Apr 24]. Available at: https://covid19.gou.go.ug/?pg=docs\&d=press

21. Uganda National Media Center. President Museveni COVID-19 Guidelines to the Nation on Corona Virus | Uganda Media Centre [Internet]. 2020 [cited 2020 Apr 24]. Available at: https://www.mediacentre.go.ug/ media/president-museveni-covidc19-guidelines-nationcorona-virus

22. Tedros A. G. WHO Director-General's opening remarks at the media briefing on COVID-19 - 11 March 2020. World Health Organization. 2020. Available at: https://www. who.int/dg/speeches/detail/who-director-general-sopening-remarks-at-the-media-briefing-on-covid-19--11-march-2020

23. Kigongo J. Six Chinese convicted for escaping from COVID-19 quarantine in Uganda - Daily Monitor [Internet]. 2020 [cited 2020 May 2]. Available at: https://www.monitor.co.ug/News/National/Six-Chineseconvicted-escaping-from-Covid-19-quarantine/6883345530970-1157vl6/index.html 
24. Uganda Ministry of Health. $\mathrm{MOH}$ press release-21st March 2020-1st COVID-19 case confirmed [Internet]. 2020. Available at: https://covid19.gou.go.ug/?pg=docs $\& d=$ press

25. Henry GM. Update on the outbreak of COVID-I9 in Uganda - COVID-19 | Ministry of Health [Internet]. 2020 [cited 2020 Apr 28]. Available at: https://www.health.go. ug/covid/2020/03/25/update-on-the-outbreak-ofcovld-I9-in-uganda/

26. World Health Organization. Coronavirus disease 2019 (COVID-19) Situation Report-62. 2020;(March). Available at: https://www.who.int/emergencies/diseases/novelcoronavirus-2019/situation-reports

27. Nyeko O. Ugandans Trying to Get Home Forced to Pay for COVID-19 Quarantine | Human Rights Watch [Internet]. 2020 [cited 2020 May 2]. Available at: https://www.hrw. org/news/2020/03/19/ugandans-trying-get-homeforced-pay-covid-19-quarantine

28. Vision TN. Coronavirus: 10 Foreigners Bribe Their Way Out of Quarantine [Internet]. 2020 [cited 2020 May 2]. Available at: https://www.newvision.co.ug/new_vision/ news/1516840/coronavirus-foreigners-bribe-quarantine

29. Observer T. Museveni imposes 14-day COVID-19 lockdown. The Observer [Internet]. 2020 [cited 2020 May 2]. Available at: https://observer.ug/news/headlines/ 64074-museveni-announces-14-day-covid19-lockdown

30. Ministry of Health- Uganda on Twitter: "The Ethiopian airlines cargo flight carrying the Jack Ma consignment just landed at Entebbe airport. As part of the Jack Ma and @AlibabaGroup support to the fight against \#COVID19, \#Uganda received: $-100,000$ masks $-20,089$ test kits 741 PPEs -1,111 face shields \#STAYSAFEUG https://t.co/ibgZpNXgmg" / Twitter [Internet]. [cited 2020 Apr 26]. Available at: https://twitter.com/ minofhealthug/status/1242437214354751491

31. Uganda Ministry of Health. Update on the Covid-19 outbreak in Uganda - Ministry of Health. 2020 [cited 2020 May 2]. Available at: https://www.health.go.ug/ cause/update-on-the-covid-19-outbreak-in-uganda-2/

32. Bhuckory K, Ojambo F. Uganda, Africa Coronavirus News: Museveni Closes Borders - Bloomberg [Internet]. 2020 [cited 2020 May 2]. Available at: https://www.bloomberg. com/news/articles/2020-03-22/uganda-to-closeborders-after-reporting-first-virus-infection
33. Segawa M. More people in Uganda to die of hunger than Coronavirus - Watchdog Uganda [Internet]. 2020 [cited 2020 May 2]. Available at: https://www.watchdog uganda.com/op-ed/20200327/89771/more-people-inuganda-to-die-of-hunger-than-coronavirus.html

34. Agaba J. Uganda's 'urban poor' fear dying of hunger during COVID-19 lockdown - Alliance for Science [Internet]. 2020 [cited 2020 May 2]. Available at: https://allianceforscience.cornell.edu/blog/2020/04/uga ndas-urban-poor-fear-dying-of-hunger-during-covid19-lockdown/

35. Uganda Bureau of statistics. Urban Labour Force Survey 2015. 2015. [cited 2020 May 3] Available at: https://www.ubos.org/

36. Etukuri C. Security Urges Ugandans To Abide By The Curfew Directive. New Vision [Internet]. 2020 [cited 2020 May 2]. Available at: https://www.newvision.co.ug/ new_vision/news/1517785/security-urges-ugandansabide-curfew-directive

37. Kahungu T. Government to provide maize flour, beans to vulnerable people. Daily Monitor [Internet]. 2020 [cited 2020 May 2]. Available at: https://www.monitor.co.ug/ News/National/Govt-to-distribute-food-1-5m-peopleWakiso-Kampala/688334-5511284-10wt835/index.html

38. Parliament of Uganda. MPs demand countrywide relief food distribution. 2020 [cited 2020 May 2]. Available at: https://www.parliament.go.ug/news/4595/mpsdemand-countrywide-relief-food-distribution

39. World Health Organization. Uganda: WHO COVID-19 Dashboard [Internet]. 2020 [cited 2020 May 2]. Available at: https://covid19.who.int/region/afro/country/ug

40. Daily Monitor Uganda. Museveni to issue new COVID-19 guidelines before May 5 [Internet]. 2020 [cited 2020 May 6]. Available at: https://www.monitor.co.ug/News/ National/Museveni-COVID19-guidelines-MPs-Kadagatruckers-/688334-5537312-9c1eyd/index.html

41. Yoweri Kaguta M. Statement on COVID19 pandemic and latest guidelines | President Yoweri Kaguta Museveni [Internet]. 2020 [cited 2020 May 6]. Available at: https://www.yowerikmuseveni.com/statementcovid19-pandemic-and-latest-guidelines

42. Ugandan Ministry of Health. Update on the Covid-19 Outbreak in Uganda. 2020 [cited 2020 May 6]. Available at: https://www.health.go.ug/cause/update-on-thecovid-19-outbreak-in-uganda-4/ 
43. Leni X. COVID-19 CRISIS: Uganda using chloroquine to treat coronavirus patients. PML Daily [Internet]. 2020 [cited 2020 May 6]. Available at: https://www.pmldaily. com/news/2020/04/covid-19-crisis-uganda-usingchloroquine-to-treat-coronavirus-patients.html

44. Ugandan Ministry of Health. Update on the Covid-19 Outbreak in Uganda. 2020 [cited 2020 May 6]. Available at: https://www.health.go.ug/cause/update-on-thecovid-19-outbreak-in-uganda-4/

45. Ugandan Ministry of Health. Press Release Archives COVID-19. 2020 [cited 2020 May 6]. Available at: https:// www.health.go.ug/covid/category/press-release/

46. Denyer S, Kim MJ. South Korea is doing 10,000 coronavirus tests a day | The Seattle Times [Internet]. 2020 [cited 2020 Apr 26]. Available at: https://www.seattletimes.com/nation-world/southkorea-is-doing-10000-coronavirus-tests-a-day/

47. Julia $\mathrm{H}$, Yoonjung $\mathrm{S}$. South Korea is holding an election during the coronavirus crisis. Other countries are postponing theirs. CNN [Internet]. 2020 [cited 2020 May 3]. Available at: https://edition.cnn.com/2020/04/13/asia /elections-coronavirus-pandemic-intl-hnk/index.html

48. Abet T. Covid-19: Government on alert as fake test kits hit market. Daily Monitor [Internet]. 2020 [cited 2020 May 3]. Available at: https://www.monitor.co.ug/News/ National/Covid-19-Government-alert-fake-test-kits-hitmarket/688334-5512932-nrc6lz/index.html

49. Costello A. Mass testing is the only way to stop the virus - it's long overdue. The Guardian [Internet]. 2020 [cited 2020 May 3]. Available at: https://www.theguardian.com /commentisfree/2020/mar/25/mass-covid-19-testing-isvital-but-the-data-must-be-localised

50. Mbabazi FK. Projection of COVID-19 Pandemic in Uganda. BMJ Yale. 2020;2. (doi: 10.1101/2020.04.02.20051086).

51. Ampurire P. With No Lockdown, Uganda Could Have Had 18,000 COVID-19 Cases and 566 Deaths by End of April. SoftPower News [Internet]. 2020 [cited 2020 May 6]. Available at: https://www.softpower.ug/with-nolockdown-uganda-could-have-had-18000-covid-19cases-and-566-deaths-by-end-of-april/
52. World Health Organization Regional Office for Africa. Situation reports on COVID-19 outbreak - Sitrep 07, 15 April 2020. 2020 [cited 2020 Apr 24]. Available at: https://www.afro.who.int/publications/situationreports-covid-19-outbreak-sitrep-07-15-april-2020

53. Wu JT, Leung K, Bushman M, Kishore N, Niehus R, de Salazar PM, et al. Estimating clinical severity of COVID-19 from the transmission dynamics in Wuhan, China. Nat Med. 2020;26:506-10. (doi: 10.1038/s41591-020-0822-7).

54. Onder G, Rezza G, Brusaferro S. Case-Fatality Rate and Characteristics of Patients Dying in Relation to COVID-19 in Italy. JAMA. 2020. (doi: 10.1001/jama.2020.4683).

55. Santacroce L, Charitos IA, Del Prete R. COVID-19 in Italy: An Overview from the First Case to Date. Electron J Gen Med. 2020;17(6):em235. (doi: 10.29333/ejgm/7926).

56. Walter LA, McGregor AJ. Sex- and Gender-specific Observations and Implications for COVID-19. Western Journal of Emergency Medicine: Integrating Emergency Care with Population Health, 21(3). (doi: 10.5811/westjem.2020.4.47536).

57. Uganda Bureau of Statistics TN 2014-MR. The National Population and Housing Census 2014-Main Report. 2016 [Cited 2020 May 06]. Available at: https://www.ubos.org/ wp-content/uploads/publications/03_20182014_ National_Census_Main_Report.pdf

58. Cowling BJ, Ali ST, Ng TWY, Tsang TK, Julian CM, Li MWF, et al. Impact assessment of non-pharmaceutical interventions against COVID-19 and influenza in Hong Kong: an observational study. MedRxiv. 2020. (doi: 10.1101/2020.03.12.20034660).

59. Musinguzi G, Asamoah BO. The Science of Social Distancing and Total Lock Down: Does it Work? Whom does it Benefit? 2020;17(6):17-9. (doi: 10.29333/ejgm/7895).

60. Lau H, Khosrawipour V, Kocbach P, Agata M, Schubert J, Bania J, et al. The positive impact of lockdown in Wuhan on containing the COVID-19 outbreak in China, Journal of Travel Medicine, taaa037. (doi: 10.1093/jtm/taaa037).

61. Margaret H, Tedros AG, Michael R, Jamil, Dewillio, Maria VK, et al. World Health Organization: COVID-19 virtual press conference - 25 March 2020. 2020;(February 2019):1-13. Available at: https://www.who.int/dg/spee ches/detail/who-director-general-s-opening-remarksat-the-media-briefing-on-covid-19---25-march-2020 
62. Stephen K, Christine T, Marc L, Yonatan H G. Social distancing strategies for curbing the COVID-19 epidemic. MedRxiv. 2020;(3). (doi: 10.1101/2020.03.22.20041079).

$\diamond \diamond \diamond$ 